Review

\title{
Involvement of microRNA in Solid Cancer: Role and Regulatory Mechanisms
}

\author{
Ying-Chin Lin ${ }^{1,2,+}$, Tso-Hsiao Chen ${ }^{3,+}$, Yu-Min Huang ${ }^{4,5} \mathbb{D}$, Po-Li Wei ${ }^{4,6,7,8,9, * \mathbb{D}}$ and Jung-Chun Lin $10,11,12, * \mathbb{D}$ \\ 1 Department of Family Medicine, School of Medicine, College of Medicine, Taipei Medical University, \\ Taipei 110, Taiwan \\ 2 Department of Family Medicine, Wan Fang Hospital, Taipei Medical University, Taipei 116, Taiwan; \\ greening1990@gmail.com \\ 3 Division of Nephrology, Wan Fang Hospital, Taipei Medical University, Taipei 116, Taiwan; \\ 88128@w.tmu.edu.tw \\ 4 Department of Surgery, School of Medicine, College of Medicine, Taipei Medical University, \\ Taipei 110, Taiwan \\ 5 Division of Gastrointestinal Surgery, Department of Surgery, Taipei Medical University Hospital, \\ Taipei Medical University, Taipei 110, Taiwan; yuminhuang26@gmail.com \\ 6 Division of Colorectal Surgery, Department of Surgery, Taipei Medical University Hospital, \\ Taipei Medical University, Taipei 110, Taiwan \\ 7 Cancer Research Center, Taipei Medical University Hospital, Taipei Medical University, Taipei 110, Taiwan \\ 8 Translational Laboratory, Department of Medical Research, Taipei Medical University Hospital, \\ Taipei Medical University, Taipei 110, Taiwan \\ 9 Graduate Institute of Cancer Biology and Drug Discovery, Taipei Medical University, Taipei 110, Taiwan \\ 10 School of Medical Laboratory Science and Biotechnology, College of Medical Science and Technology, \\ Taipei Medical University, Taipei 110, Taiwan \\ 11 Program in Medical Biotechnology, College of Medical Science and Technology, Taipei Medical University, \\ Taipei 110, Taiwan \\ check for \\ updates \\ Citation: Lin, Y.-C.; Chen, T.-H.; \\ Huang, Y.-M.; Wei, P.-L.; Lin, J.-C. \\ Involvement of microRNA in Solid \\ 12 Pulmonary Research Center, Wan Fang Hospital, Taipei Medical University, Taipei 110, Taiwan \\ * Correspondence: poliwei@tmu.edu.tw (P.-L.W.); lin2511@tmu.edu.tw (J.-C.L.); \\ Tel.: +886-2-2736-1661 (ext. 3330) (J.-C.L.) \\ + Ying-Chin Lin and Tso-Hsiao Chen contributed equally to this work.
} Cancer: Role and Regulatory Mechanisms. Biomedicines 2021, 9, 343. https://doi.org/10.3390/

biomedicines 9040343

Academic Editor: Francesca Lovat

Received: 25 February 2021

Accepted: 24 March 2021

Published: 29 March 2021

Publisher's Note: MDPI stays neutral with regard to jurisdictional claims in published maps and institutional affiliations.

Copyright: (c) 2021 by the authors. Licensee MDPI, Basel, Switzerland. This article is an open access article distributed under the terms and conditions of the Creative Commons Attribution (CC BY) license (https:// creativecommons.org/licenses/by/ $4.0 /)$
Abstract: MicroRNAs (miRNAs) function as the post-transcriptional factor that finetunes the gene expression by targeting to the specific candidate. Mis-regulated expression of miRNAs consequently disturbs gene expression profile, which serves as the pivotal mechanism involved in initiation or progression of human malignancy. Cancer-relevant miRNA is potentially considered the therapeutic target or biomarker toward the precise treatment of cancer. Nevertheless, the regulatory mechanism underlying the altered expression of miRNA in cancer is largely uncovered. Detailed knowledge regarding the influence of miRNAs on solid cancer is critical for exploring its potential of clinical application. Herein, we elucidate the regulatory mechanism regarding how miRNA expression is manipulated and its impact on the pathogenesis of distinct solid cancer.

Keywords: microRNA; solid cancer; post-transcriptional regulation

\section{Introduction}

Activation of tumorigenic processes mediate the neoplasia of normal cells, potentially resulting in initiation of malignancy. Exploration of regulatory mechanism relevant to the occurrence or progression of diverse cancers can be subjected to clinical application, such as early prevention, precise screening, or personal treatment. Among the regulatory factor involved in altered gene expression associated with carcinogenesis, the influence of microRNAs (miRNAs) has been widely pursued for decades [1]. MiRNA is a 22 ntlong noncoding RNA that functions as a post-transcriptional regulator for fine-tuning the coding efficiency of messenger RNA (mRNA) [2]. Targeting of the RNA-induced silencing complex (RISC) composed of single- strand miRNA, Argonaute (AGO), and 
GW182 (also known as TNRC6A) mediates the translational repression or degradation of the. regulatory candidate [3]. miRNA-mediate regulation is relevant to diverse cellular or environmental stress, including starvation, oxidative stress, hypoxia, and DNA breakdown, thereby being implicated in malignant disease [4]. Accordingly, dysregulation of miRNA expression is documented to exhibit bidirectional impact toward oncogenesis or tumor suppression [5].

Disturbance in miRNA expression can be induced via multiple steps, including transcriptional regulation, epigenetic methylation of miRNA-containing loci, miRNA processing pathway, and sequestration with long non-coding RNA, which functions as the miRNA sponge (Figure 1) [6,7]. For instance, various p53-responsive miRNAs networks containing miR-34 or miR-27b is documented to mediate the quiescence of distinct cancer cells $[8,9]$. The presence of mutant p53 reversely diminishes the tumor suppressive influence of p53-regulated miRNAs on carcinogenic signature [10]. Recent studies disclose the correlation between miRNA expression and epigenetic control regarding the methylation of CpG island within promoter region in cancer [11]. The silence of miR-127, miR-124-1, or miR-129-2 is closely related to the hypermethylation of CpG island-containing promoter in various solid cancer [12-14]. In addition, the function or expression of miRNA processing machinery, such as Drosha or the DGCR8 protein, is frequently deregulated in diverse malignancies [15]. Even though the impact of Drosha or DGCR8 on carcinogenesis is controversial, the disturbance of miRNA processing machinery is closely related to the global change in the miRNA expression profile [16]. The mutations of Dicer gene lead to DICER1 syndrome, which is relevant to the incidence of multiple cancers in an individual [17]. The biogenesis of miRNAs and gene expression profiles is disrupted with the mutant Dicer protein [18]. Recent studies document that miRNA loci are frequently annotated within the chromosomal regions, which are susceptible to the cancer-associated copy number variation (CNV) [19]. Cancer-mediated genomic instability results in the amplification or deletion of miRNA loci, subsequently leading to variation in the miRNA copy number [20].

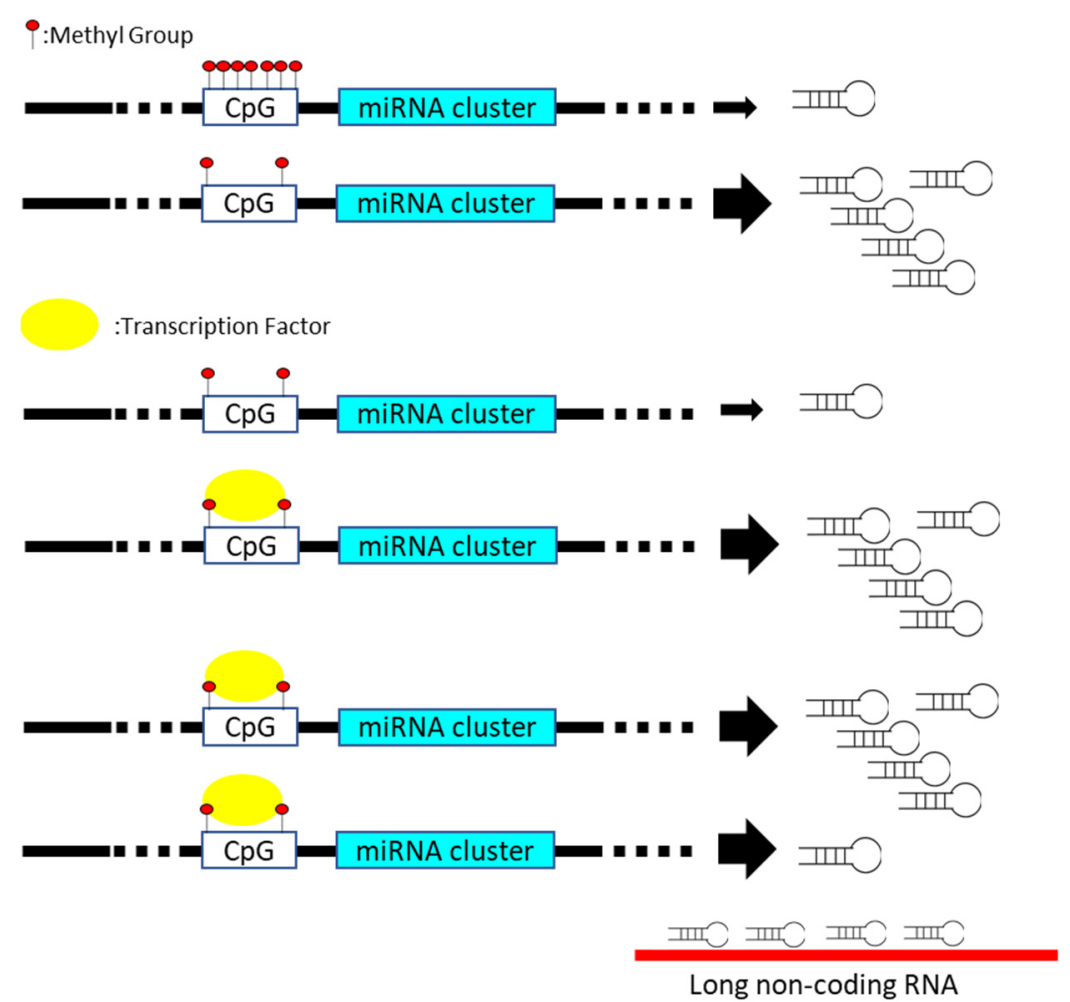

Figure 1. miRNA gene expression is manipulated via distinct mechanisms, including methylation (upper), transcription regulator (middle), and miRNA sponge (lower) in cancer cells. 
According to the evidence gathered to date, we summarize the current knowledge regarding the impact of miRNA on the pathogenesis of frequent solid cancer, including colorectal cancer, lung cancer, breast cancer, and liver cancer. This review additionally evaluates the advantage or challenge associated with miRNA-based application in cancer treatment.

\section{MiRNA and Solid Cancer}

\subsection{Colorectal Cancer}

Colorectal cancer (CRC) is identified as the second leading cause of cancer-associated deaths worldwide with its high mortality and an increase in incidence [21]. In spite of progress in early screening, diagnosis, or prognostic prediction toward the incidence of CRC, miRNA is considered to be a potential biomarker for the assessment of CRC progression [22]. Decreases in the expression of miRNA clusters are frequently identified with the occurrence or development of CRC [23]. In the following section, the impact of several miRNA clusters on CRC are addressed.

\subsection{Tumor-Suppressive miRNA in CRC}

\subsubsection{Clusters miR-1/133a and miR-206/133b}

The miR-1-1/133a-2, miR-1-2/133a-1, and miR-206/133b clusters are transcribed from distinct host genes. The influence of these miRNAs on the development of striated muscle has been widely documented [24]. Hypermethylation of the promoter within the host gene results in the decrease in the expression of miR-1/133 cluster in CRC tissues [25]. Moreover, miR-133 and 206 are specifically sponged by the complementary long non-coding RNA (lncRNA) ABHD11-AS1, XIST, and multiple LINC RNAs [26-28]. With the inhibitory effect toward the carcinogenic signatures, miR-1, miR-133a, and miR-206 are considered to be the tumor suppressors targeting a wide range of specific candidates. The in vitro results indicate the repressive effect of miR-1 on proliferation, migration, motility, and metabolism of CRC cells by targeting vascular endothelial growth factor (VEGF), notch receptor 3 (NOTCH3), and hypoxia-inducible factor 1 subunit alpha (HIF1A) gene [29-31]. The presence of miR-133 is demonstrated to diminish the growth or motility of CRC cells by targeting multiple candidates, such as fascin actin-bundling protein 1 (FSCN1) and oncogenic SUMO-specific peptidase 1 (SENP1) gene [32]. Upregulated miR-206 is relevant to reduced migration, proliferation, and immortality of CRC cells via targeting formin-like 2 (FMNL2), NOTCH3, and BCL2 gene [33].

\subsubsection{Clusters miR-15a/16-1 and $\mathrm{miR}-15 \mathrm{~b} / 16-2$}

miR-15 and miR-16 are encoded from two paralogues, miR-15a/16- 1 and miR-15b/162 in the human genome. In CRC cells, an increase in the sirtuin 1 (SIRT1) protein mediates the down-regulated activity of promoter, which drives the transcription of miR-15b/16-2 cluster [34]. In addition, the mature miR-15/16 is sequestered by upregulated sponge LINC RNAs in distinct CRC cells $[35,36]$. Both in vivo and in vitro studies demonstrate the tumorsuppressive effect that is attributed to the presence of miR-15/16 clusters in CRC [37,38]. miR-15 and miR-16 are documented to target common candidates, including cyclin B1 and transcription factor AP-4, which majorly participated in the epithelial mesenchymal transition (EMT) [39]. Exogenous expression of miR-15 is reported to suppress the growth of CRC cells by targeting pro-survival BCL2 protein [40]. The presence of overexpressing miR-16 mediates the decrease in mortality and growth of CRC cells via suppressing the expression of KRAS proto-oncogene, GTPase (KRAS) protein both in vivo and in vitro [41]. Moreover, the reverse correlation between miR-16 level and VEGF receptor or MYB protooncogene is relevant to the prognosis of CRC patient [42].

\subsubsection{Clusters miR-100/let-7a/miR-125 and miR-99/let-7c}

miR-100/let-7a/miR-125 and miR-99/let-7c are separately transcribed from an independent host gene in human genome but categorized in the same family with the related 
function. Nevertheless, the regulatory mechanism contributes to the alteration of the abovementioned miRNA clusters in CRC cells or tissues not comprehensively disclosed. For example, the abundance of sponge lncRNA is reversely relevant to the level of let-7a in CRC model [43]. The expressions of miR-125a/125b are manipulated through a complex process, including transcriptional control, hypermethylation-regulated epigenetic regulation, or sequestration with IncRNAs [44,45]. Nevertheless, the decreases in these miRNAs are frequently identified in CRC patients with poor prognosis [46]. An increase in the let-7 members mediates the cell cycle arrest and diminished cell growth via targeting of PHD and ring finger domains 2, Rho effector rhotekin, insulin-like growth factor 1, or MYC genes [47-49]. Upregulation of let-7c or let-7e lessens the metastatic activity of CRC cells through targeting the candidates encoding matrix metallopeptidase 11, PBX homeobox 3 , and double cortin-like kinase 1 protein $[50,51]$. Furthermore, the impact of the let-7 family member on the abovementioned candidates sensitizes the CRC cells toward the chemo- or radiotherapy [52]. The expression profiles of miR-99a/99b are relevant to the level of the mechanistic target of rapamycin kinase (MTOR) protein in CRC cell lines [53]. Overexpression of the miR-125 family member facilitates the apoptosis of CRC cells by targeting the related factor, such as BCL2, BCL2 family members like 12, and myeloid cell leukemia 1 (Mcl-1) gene [54]. Moreover, an increase in miR-125a level leads to the suppression of angiogenic or metastatic activity of CRC cells by targeting VEGFA, SMAD-specific E3 ubiquitin protein ligase 1, and cAMP-responsive element-binding protein 5 gene $[55,56]$.

\subsection{Lung Cancer}

Lung cancer (LC) is the leading cause of cancer-associated deaths worldwide, resulting in over 1 million deaths annually [57]. It is classified into two subsets according to the pathological signature-small cell lung cancer and non-small cell lung cancer. The complex mechanism involved in tumor initiation or progression is not comprehensively elucidated, which impedes the application of gene-based screening. A growing body of evidence indicates the association between the occasion of LC and the altered miRNA expression, which can be divided into oncomiR and tumor-suppressive miRNAs.

\subsubsection{Oncogenic miRNAs in LC Cells}

MiRNA is widely considered a pivotal regulator in the control of cells growth [58]. With an increase in MYC expression, mis-regulated amplification of human miR-17-92 cluster, composed of six miRNAs, is noted in various solid tumor, including LC. An increase in the miR-17 cluster frequently leads to upregulated cell proliferation by targeting antiapoptotic factors, including transcription factor E2F1 or Phosphate and tensin homolog (PTEN) protein [59]. Immortality is a hallmark of cancerous cells, which is closely correlated with the decrease in p53 protein as previously illustrated [8,9]. In LC cells, the transcription of miR-34 family members is directly interfered with by the reduced p53 expression [60]. The cell cycle is subsequently disturbed by the augmentation of cyclin E2 and cyclindependent kinase, which is targeted by the miR-34 family in normal cells [60]. In contrast, the ectopic expression of miR-125b or miR-504 is both demonstrated to target p53 gene and in turn lessens the apoptotic sensitivity of LC cells toward environmental stress [61,62]. Metastasis of cancerous cells constitutes a predominant cause, which leads to the majority of cancer deaths [63]. Lung cancer is frequently diagnosed with the formation of metastases in the brain, bones, liver, and adrenal glands [64]. Activation of metastasis is associated with expression profiles of internal factors as well as external regulators involved in EMT process $[65,66]$. An increase in miR-10b level functions as a major factor attributed to active metastasis or enhance other oncogenic signatures of NSCLC cells $[67,68]$.

\subsubsection{Tumor-Suppressive miRNAs in LC}

Angiogenesis functions as a critical process toward the initiation and growth of solid tumor [69]. Throughout the process, the expression of VEGF and related regulation in response to hypoxia, such as the Akt/eNOS pathway, constitutes a crucial mechanism [70]. 
The presence of overexpressing miR-128 is demonstrated to exert repressive influence toward the phosphorylation of PI3K and p38 MAPK signaling, in turn lessening the levels of VEGFA, VEGF receptor (VEGFR) 2, and VEGFR3 [71]. The suppressive effect of miR206 on angiogenic activity of NSCLC is achieved by targeting STAT3, HIF-1, or VEGF pathway [72]. The suppressive impact of miR-135a on IGF-1 expression further mediates the decreases in angiogenesis-related factors, including VEGF, bFGF, and IL-8 protein in A549 cells [73]. The decreases in various miRNAs mediate the loss of the tumor-suppressive effect on metastasis of LC. For instance, the restoration of miR-126 generation consequently inhibits the metastatic activity of NSCLC cells via targeting the chemokine receptor 1 gene [74]. Targeting of the ectopically expressing miR-192-5p on the TRIM44 gene is highly relevant to the reduced metastasis of LC cells, which is associated with the inactivation of the AKT/mTOR signaling pathway [75]. A decrease in miR-7-5p lessens its effect on repressing expression of NOVA2, which acts as an important regulator participating in angiogenesis and growth of NSCLC [76]. miR-206 exerts its tumor-suppressive impact on NSCLC metastases via targeting the actin-binding protein coronin $1 C$ gene, which mediates the growth and metastasis in other solid cancers as well [77]. Overexpression of the miR-335 leads to reduction of the TGF $\beta$-mediated EMT process in NSCLC by downregulating the level of ROCK1 gene, which plays an activator role in the PI3K/AKT/FAK pathway [78]. The presence of the miR-98 interferes with the translational activity of the TGF $\beta R 1$ gene, subsequently diminishing the proliferation, migration, and invasion in distinct LC cell lines [79]. In contrast, the let-7 family or miR-126 is demonstrated to exert a suppressive impact on the proliferation of LC cells [80]. Exogenous expression of let-7 family member is reported to diminish proliferation of the LC cells via targeting the ras gene [81]. In NSCLC cells, the presence of miR-126 is relevant to the downregulated activity of PTEN/PI3K/AKT signaling, which critically control the cell growth [82].

\subsection{Breast Cancer}

Breast cancer (BC) is classified as the major cause in terms of high morbidity and mortality in women worldwide [83]. Obesity is often related to an aberrantly high level of estrogen, estrogen receptor (ER), progesterone receptor (PR), or human epidermal growth factor receptor (HER2), which constitutes the predominant mechanism for the initiation and progression of $\mathrm{BC}$. Accordingly, miRNA involved in the regulation of adipogenesis is considered to be a potential factor to $\mathrm{BC}$ development [84]. In addition to CRC, misregulated expression miRNA cluster is frequently identified in BC [85].

\subsubsection{Oncogenic miRNAs in BC}

An increase in this miR-183/96/182 cluster, which is located at 7q32.2, is identified in a variety of malignancies, including BC [86]. Bi-directional function of the miRNA cluster for oncogenesis or tumor suppressor is documented with the results of functional assays. Nevertheless, the alteration of this cluster is related to various cell process, such as apoptotic response, DNA repair, metabolism, or EMT process [87]. The transcription of the miR-183/96/182 cluster is activated with the increases in ZEB1 (zinc finger E-box binding homeobox 1) and HSF2 (heat shock transcription factor 2) protein in BC [86]. Moreover, activation of the HIF1 or PI3K/Akt pathway constitutes an additional mechanism attributed to the upregulation of the miR-183/96/182 cluster [88]. A growing body of study demonstrates that the presence of miR-183 manipulates the expression profiles composed of 45 genes in BC, including Programmed Cell Death 4, Early Growth Response1, Integrin Subunit Beta 1, p21, and p27, which is relevant to the abovementioned cell processes [89,90]. The presence of upregulated miR-96 facilitates the proliferation and migration of $\mathrm{BC}$ cells via targeting the protein tyrosine phosphatase, non-receptor type 9 gene [91]. Moreover, increases in the miR-96 and miR-182 synchronously interfere with the translation of FOXO1 protein, which maintains the homeostasis of glucose metabolism in normal lineages [92]. The members of the miR-183/96/182 cluster are incidentally noted in the exosome collected 
from the BC patients. Taken together, the miR-183/96/182 cluster mainly functions as the oncogenic factor toward the development of $\mathrm{BC}$.

The miR-221/222 cluster is transcribed from Xp11.3 to encode two homologous miRNA members. The increases in miR-221/222 are highly relevant to the active cell proliferation, EMT process, and metastatic activity in BC cells via targeting a variety of tumor suppressors, including Transcriptional Repressor GATA Binding 1, Adiponectin Receptor 1, Suppressor of Cytokine Signaling 1, Cyclin Dependent Kinase Inhibitor 1B, $\mathrm{ER} \alpha, \mathrm{p} 27$, and TIMP Metallopeptidase Inhibitor 3 genes [93]. Upregulation of miR-221/222 leads to the transformation of ER- $\alpha$ positive tumors to ER- $\alpha$ negative BC by targeting the ER- $\alpha$ gene [94]. Moreover, the aberrant expression of the miR-221/222 cluster is advantageous to self-renewal of the BC stem cell self by targeting the PTEN-Akt signaling pathway [95]. Taken together, the miR-221/222 acts as a predominant oncogene in the origin of ER-negative BC with the aggressive signature.

\subsubsection{Tumor-Suppressive miRNAs in BC}

The miR-199a/214 cluster is annotated at chromosome1q24 to generate miR-199a-5p, miR-199a-3p, and miR-214 transcripts. The hedgehog-signaling Vitamin D Receptor and miR-214 are demonstrated to constitute a cross-talk axis involved in the downregulation of miR-199/214 expressions in BC cells [96]. The decrease in the miR-199/214 cluster results in the loss of its tumor-suppressive effect in triple negative BC (TNBC). For instance, depletion of the miR-199a/214 cluster induces the EMT-like phenotype in normal cell lineage [85]. Overexpression of the miR-199a/214 cluster reversely lessens the proliferative activity of TNBC cells by targeting hedgehog signaling, which is proposed as a potential therapeutic strategy toward BC [96]. The H3K27me3-related epigenetic silencing is associated with the levels of the Enhancer of zeste homolog 2 (Ezh2) protein, which induces neoplasia in various tissues. The inverse correlation between the miR-199/214 and Ezh2 or Ki-67 protein is identified by using an in vitro BC cell model [97]. The impact of miR-199/214 on interfering with the generation of Ezh2, $\beta$-catenin, or Ki-67 constitutes another mechanism for diminishing the proliferative activity of $\mathrm{BC}$ cells $[98,99]$. Accordingly, the tumorsuppressive influence of miR-199/214 cluster on inhibiting proliferation, migration, and invasion of $\mathrm{BC}$ cells is documented with majority of the present studies.

\subsubsection{Oncogenic and Tumor-Suppressive of miR-23/27/24 Cluster}

Two paralogs of this cluster, miR-23a/27a/24-2 and miR-23b/27b/24-1, are respectively annotated in chromosomes 19 and 9 . The results of functional studies suggest that the transcribed member of the cluster executes both oncogenic and tumor-suppressive effects on the carcinogenic signature of BC cells. Upregulated transcription of miRNA-23/27/24 induces the progression of $\mathrm{BC}$ cells via targeting the Hypermethylated in Cancer 1 gene, which functions as a repressor to tumor growth [100]. Nevertheless, the impact of miR-23b and miR-27b targeting on tumor growth is controversial, based on the in vitro cultured or in vivo nude mice model [101]. Moreover, the members of this cluster share a variety of candidates, such as Sprouty RTK Signaling Antagonist 2, BCL2 Antagonist/Killer, PPAR $\gamma$, and Nischarin gene [102]. This miRNA cluster also exerts its influence by collaborating with other miRNAs on BC development. For instance, FOXO1 expression is coordinatively regulated by the miRNA-23/27/24 cluster along with miR-27a, miR-96, or miR-182 in $B C$ [92]. In contrast, targeting of miR-27a to the Transmembrane Protein 170B gene is demonstrated to suppress the Wnt/ $\beta$-catenin pathway, in turn lessening the proliferative and migratory efficiency of BC cells [103]. Moreover, targeting of the overexpressing miR-23b-3p to PAK2 and phosphorylation of the myosin light chain II gene subsequently reduces the metastatic activity of $B C$ cells in vitro [104]. Taken together, the comprehensive insight into the manipulation of miRNA-23/27/24 expression and its coordination with other miRNA is useful in controlling BC development. 


\subsection{Liver Cancer}

Hepatocellular carcinoma (HCC) is identified as the third cause of cancer mortality in the Asia-Pacific region, which consequently accounts for over $80 \%$ of liver cancers [105]. In addition to viral infection, aflatoxin-contaminated food-, alcohol-, or obesity-mediated cirrhosis, the impact of miRNA is demonstrated in the context of HCC [106]. With its potential to manipulate gene expression profiles, miRNA is practicable as a novel therapeutic or emerging biomarker for the stratification of HCC patient.

\subsubsection{Oncogenic miRNAs in HCC}

miR-21 is a well-characterized oncomiR in a variety of solid tumors, including HCC [107]. An increase in miR-21 level with the incident of HCC is consistently revealed by using in vitro and in vivo experiments [108]. Aberrant expression of miRNA-21 with a concomitant decrease in tumor-suppressive PTEN protein leads to activation of focal adhesion kinase, Akt, and mTOR signaling, in turn resulting in active cell metastasis and proliferation [109]. Activation of a series kinase cascade is associated with the increase in MMP-2 and MMP-9, which further strengthens the pathogenesis and development of HCC [109]. An elevated level of miR-21 in plasma potentially provides high accuracy toward the screening or diagnosis of early-stage HCC [110].

miR-221 is identified as another oncomiR with an upregulated level in HCC [111]. By directly targeting the cell cycle inhibitors, including CDKN1B/p27 and CDKN1C/p57, the influence of miR-221 on active progression of HCC is consistently disclosed in multiple studies [112]. Direct targeting of miR-221 to the DNA damage-inducible transcript 4 gene relieves its tumor-suppressive activity in HCC model [111]. Moreover, the presence of miR-221 strengthens the anti-apoptosis activity of HCC cells by manipulating the level of the Bcl2 modifying factor protein (BMF), the pro-apoptotic member of the Bcl-2 family [113]. In contrast, inhibition of miR-221 increases the susceptibility of HCC to apoptotic stimuli with an elevated level of BMF and the downstream caspase pathway [113].

\subsubsection{Tumor-Suppressive miRNAs in HCC}

miR-29 family is comprised of four members, miRNA-29a, miRNA-29b-1, miRNA-29b2, and miRNA-29c, which are transcribed from chromosomes 7q32.3 and 1q32.2. An miRNA profiling study first identified the downregulation of miR-29 in LC patients associated with poor prognosis and survival rate [114]. By using an in vitro cultured system, activation of TGF- $\beta$ or nuclear factor kappa B (NF- $\mathrm{kB}$ ) drives the downregulation of miRNA-29, in turn facilitating the expressions of extracellular matrix genes in hepatic stellate cells [115]. miR-29 family members are disclosed to share a variety of candidates, including CDC42, PIK3R1, Bcl-2, and Mcl-1 gene [116]. In line with these results, targeting of endogenous Bcl-2 and Mcl-1 gene by miR-29 family member sensitizes the HepG2 cells to apoptosisinduced chemotherapeutic treatment or serum starvation [116]. In addition to miR-29, the inverse correlation between Mcl-1 and miR-101 or miR-125b is also identified in liver tumor cells $[117,118]$. Similarly, respective targeting of miR-101 or miR-125b share the same effect on sensitizing the liver cancer cells with the presence of apoptotic treatment via targeting Mcl-1 gene. miR-122 is the most abundant miRNA, which fine-tunes a variety of cellular processes in hepatocyte [119]. The transcription of miRNA-122 is controlled by the expression of liver-specific factors, including CCAAT/enhancer-binding protein (C/EBP) and hepatocyte nuclear factor (HNF) family members [120]. A decrease in miRNA-122 level associated with hepatocarcinogenesis, active metastasis, and poor prognosis is identified in HCC tissue [121]. The presence of miRNA-122 exerts the tumor suppressive impact on HCC development via targeting cyclin G1, pyruvate kinase isoform M2, and Wnt family member 1 gene [112]. Th miR-122/cyclin G1 axis facilitates the stability of p53 and therefore promotes the sensitivity of HCC cells to doxorubicin-induced apoptosis [112]. 


\subsection{Ovarian and Cervical Cancer}

Ovarian cancer and cervical cancer is ranked as the first and fourth cause of cancer death in women worldwide [122,123], respectively. Around $65 \%$ of ovarian cancer is classified as surface epithelial according to the World Health Organization (WHO) classification [124]. Even though understanding the biological signature of ovarian cancer was gradually revealed with the recent progress and knowledge, the severity or mortality of ovarian cancer remains unchanged for the last 30 years. A promising biomarker, such as the cancer-specific miRNA, toward early screening or precise diagnosis of ovarian cancer is crucial. On the other hand, the majority of cervical cancer is initiated by the infection of certain subtypes of the human papilloma virus (HPV) [125]. The relevance of HPV infection with the chronic inflammation that subsequently mediates the initiation of cervical carcinogenesis remains controversial. Recent studies document that the aberrant miRNAs profile is identified throughout the initiation and development of cervical cancer [126]. Moreover, the altered miRNA level exhibits influence on manipulating the carcinogenic process of cervical cancer.

\subsubsection{Oncogenic miRNA in Ovarian Cancer and Cervical Cancer}

Metastasis of ovarian cancer is modulated via the interplay between miRNA and signaling factors involved in the EMT pathway [127]. An increase in miR-17-5p level is relevant to the active progression and EMT activity of ovarian cancer cells by targeting PTEN expression and downstream signaling [128]. In contrast, the administration of an miR-17-5p inhibitor interferes with the migration and invasion activity of ovarian cancer cells by using in vitro cultured assays [128]. The presence of miR-214 targets the PTEN expression, which in turn reduces the sensitivity of in vitro cultured ovarian cancer cells to cisplatin [129].

In cervical cancer, a growing body of studies demonstrate the oncogenic influence of miR-21 with the identification of diverse targets, including PDCD4, PTEN, TIMP-3, TNF- $\alpha$, and ANXA1 genes [130-132]. Therefore, upregulated miR-21 is highly related to the active inflammation and metastasis of cervical cancer cells. The upregulated level of miR-155 in peripheral blood and tissues collected from cervical cancer patients has been revealed in recent studies. The presence of miR-155 targets the expression of SOSC1, which in turn enhances progression and inflammation in cervical cancer [133].

\subsubsection{Tumor-Suppressive miRNA in Ovarian Cancer and Cervical Cancer}

A decrease in miR-150 is frequently identified in epithelial ovarian cancer cells [134]. The presence of overexpressing miR-150 lessens the invasive and metastatic activity of ovarian cancer cells by targeting the expression of Zinc Finger E-Box Binding Homeobox 1 (ZEB1) protein [135]. miR-150 is suggested as a potential therapeutic target for intervening the metastasis of ovarian cancer [135]. Similarly, the upregulation of miR-22, miR-183, or miR-31 level is reported to result in reduced migration or invasion of serous ovarian carcinoma by interfering with the expression of the TIAM1 protein [136]. Moreover, overexpressing miR-7 directly targets the expression of EGFR protein, which leads to reversion of the EMT signature in ovarian cancer through AKT and ERK1/2 pathways [137].

Multiple miRNAs exert a suppressive effect on the chronic inflammation, which is crucial for the development of cervical cancer [138]. Downregulation of miR-429 is relevant to the active inflammation in cervical cancer tissues with IL- 6 and IFN- $\beta$ production, which is driven through the NF- $\mathrm{KB}$ pathway [139]. IKK $\beta$ (the primary kinase toward NF- $\mathrm{kB}$ activation) is identified as a new target of miR-429 in cervical cancer cells [139]. miR-101 is documented to exert a tumor-suppressive impact on the proliferation, invasion, and inflammation of cervical cancer cells by directly targeting COX-2 protein [140]. The reverse association of the high mobility group box 1 (HMGB1) with miR-34a, miR-1284, and miR142 is identified in the cervical cancer cells [141-143]. HMGB1 is a well-characterized oncogene that is involved in chronic inflammation, progressive tumorigenesis, active metastasis, and therapy resistance of cervical cancer tissues. Downregulation of miR-24, 
miR-451, let-7a, and miR-125a is noted as well in cervical cancer, which is relevant to the active inflammation. An increase in chitinase-3-like protein 1 with a concomitant decrease in miR-24 is proposed to facilitate the proliferation, metastasis, and inflammation in cervical cancer [144]. The tumor-suppressive impact of miR-451 on lessening the inflammation, invasion, angiogenesis, and proliferation of cervical cancer cells is demonstrated by directly targeting the expression of the IL-6 receptor [144]. The generation of HPV oncoprotein E6 mediates the decreases in let-7a and miR-125, in turn relieving the suppressive effect of let-7a and miR-125 on STAT3 expression $[145,146]$. The presence of STAT3 further facilitates expression of the HPV E6 protein through transcriptional regulation [145]. Taken together, STAT3 and HPV E6 constitute a feed-forward circuit that participates in the downregulation of let-7a and miR-125 throughout the development of cervical cancer. Reversely, the complementation of miR-125 leads to the decreases in STAT3, MMP-9, MMP-2, and Ncadherin levels and activities, subsequently diminishing the proliferation, metastasis, and inflammation of cervical cancer cells [146].

\section{Role of Exosomal miRNA and Its Application}

Exosomes are extracellular vesicles ranging from 30 to $150 \mathrm{~nm}$ in size that can be secreted by normal or cancer cells [147]. Secretion of exosome is demonstrated to deliver a messenger, including protein or miRNA, between normal and cancer cells [148]. It is documented that cancer cells secrete 10-fold more exosomes than that of normal cells, which is critical to the recruitment and development of carcinogenic environment [149]. Taking lung cancer as an example, miR-96-containing exosomes secreted from H1299 cells were demonstrated to exhibit oncogenic activity toward upregulated cell proliferation by directly targeting the production of the LIM-domain only protein 7 (LMO7) expression [150]. The presence of exosomal miR-23a secreted by lung cancer cells was documented to facilitate tumor angiogenesis under both normoxia and hypoxia conditions, suggesting that the genetic messenger was transmitted from lung cancer cells to distant endothelial cells [151]. Furthermore, the drug resistance of lung cancer cells is closely related to the existence of exosomal miRNA. A recent study reported that the gemcitabine-resistant A549 (A549-GR) cells assembled miR-222-3p-containing exosomes, which were transmitted into parental gemcitabine-sensitive cells and subsequently promoted their migration, invasion, and gemcitabine resistance by targeting the expression of the SOCS3 protein [152]. Additionally, the transfer of the miR-21-containing exosome assemble by gefitinib-resistant H827R cells to HCC827 cells activated AKT signaling and lead to gefitinib resistance of parental gefitinib-sensitive cells [153].

Taken together, exosomal miRNA is considered an ideal tool for diagnosis as well as therapeutic targets with its influence on the carcinogenic pathway or environment. As for lung cancer cells, five exosomal miRNAs, including miR-205, miR-19a/19b, miR-30b, and miR-20a, were considered the diagnostic markers of squamous cell lung carcinoma (SQCLC) with their decreases in the circulating levels after surgery [154]. Three SQCLCrelated miRNAs, including miR-10b-5p, miR-15b-5p, and miR-320b, were demonstrated to be promising biomarkers with area under the ROC curve (AUC) values between 0.936 and 0.911 toward diagnosis of the disease [155]. In addition to diagnosis or early prediction, exosome is demonstrated as an ideal vehicle for drug delivery within recent studies [156]. For instance, the usage of engineered exosomes containing miR-21 sponge was reported to mediate a decrease in miR-21 in U87-MG glioma cell lines, in turn lessening its carcinogenic signature by relieving the miR-21-mediated suppression on the expression of PDCD4 and RECK protein [156]. Nevertheless, the problems of miRNA-mediated influence, such as off-target phenomenon, is not ignored with the promising reports.

\section{Conclusions and Perspectives}

MiRNAs are involved in diverse cell process to maintain the homeostasis of normal cells through complex network (Tables 1 and 2). This phenomenon makes aberrant miRNA profiles interesting biomarkers for initiation or progression of solid tumor as well as poten- 
tial targets for precise treatment. Nevertheless, precise targeting or site-specific delivery of solid cancer-specific miRNA could be a major impediment in the use of miRNA-based therapy. In addition, a better knowledge regarding the off-target effect and comprehensive assessment of toxicity is another critical concern to be solved. In this review, we summarize the present knowledge of miRNA-mediated influence on the carcinogenic signature of frequent solid tumor, which may highlight a potential opportunity for clinical translation and potential application. 
Table 1. The impact of classified oncomiR on the carcinogenic signature through the specific target.

\begin{tabular}{|c|c|c|c|c|c|}
\hline miRNA & Disease & Manipulating Mechanism & Candidate & Physiological Influence & Reference \\
\hline miR-17 & LC; Ovarian cancer & $\begin{array}{l}\text { CNVs; Transcriptional control } \\
\text { (MYC) }\end{array}$ & E2F1, PTEN & $\begin{array}{l}\text { Cell Growth, apoptosis, } \\
\text { metastasis }\end{array}$ & {$[55,128]$} \\
\hline $\mathrm{miR}-125 \mathrm{~b}$ & LC & Epigenetic control & p53 & Apoptosis & {$[60]$} \\
\hline miR-504 & $\mathrm{LC}$ & $\begin{array}{l}\text { Transcriptional control (EGFR } \\
\text { signaling) }\end{array}$ & p53 & Apoptosis & [61] \\
\hline miR-10b & LC & Epigenetic control & Homeobox D10, & Metastasis & {$[71,72]$} \\
\hline miR-183 & $\mathrm{BC}$ & $\begin{array}{c}\text { Transcriptional control (ZEB1, } \\
\text { HSF2) }\end{array}$ & PCD4, EGR1, p21, p27 & $\begin{array}{l}\text { Apoptosis, DNA repair, } \\
\text { metabolism, EMT }\end{array}$ & [84-86] \\
\hline miR-96 & $\mathrm{BC}$ & miRNA sponge & FOXO1, PTPN9 & $\begin{array}{c}\text { Proliferation, migration, } \\
\text { metabolism }\end{array}$ & [87] \\
\hline miR-182 & $\mathrm{BC}$ & miRNA sponge & FOXO1 & Metabolism & [88] \\
\hline $\mathrm{miR}-221 / 222$ & $\mathrm{BC}$ & $\begin{array}{c}\text { Epigenetic control, miRNA } \\
\text { sponge, transcriptional control } \\
(\text { TGF- } \beta)\end{array}$ & $\begin{array}{c}\text { Transcriptional Repressor GATA } \\
\text { Binding 1, Adiponectin Receptor } \\
\text { 1, Suppressor of Cytokine } \\
\text { Signaling 1, Cyclin Dependent } \\
\text { Kinase Inhibitor 1B, ER } \alpha, \text { p27, } \\
\text { and TIMP Metallopeptidase } \\
\text { Inhibitor } 3 \\
\end{array}$ & $\begin{array}{l}\text { Proliferation, EMT process, } \\
\text { metastasis }\end{array}$ & [89] \\
\hline $\mathrm{miR}-23 / 27 / 24$ & $\mathrm{BC}$ & Transcriptional control (HIC1) & $\begin{array}{c}\text { Hypermethylated in Cancer } 1 \\
\text { (HIC1), Sprouty RTK Signaling } \\
\text { Antagonist 2, BCL2 } \\
\text { Antagonist/Killer, PPAR } \gamma, \\
\text { Nischarin, Transmembrane } \\
\text { Protein 170B, PAK2 }\end{array}$ & Cell growth, migration & {$[88,99,100]$} \\
\hline miR-21 & HCC; Cervical Cancer & miRNA sponge & $\begin{array}{l}\text { PTEN, MMP2, MMP9, PDCD4, } \\
\text { PTEN, TIMP-3, TNF- } \alpha \text {, ANXA1 }\end{array}$ & Metastasis and proliferation & {$[105,130-132]$} \\
\hline $\operatorname{miR}-221$ & HCC & Transcriptional control (NF-kB) & $\begin{array}{l}\text { CDKN1B/p27, CDKN1C/p57 } \\
\text { DNA damage-inducible } \\
\text { transcript } 4, \text { BMF }\end{array}$ & Cell growth, apoptosis & {$[108,109]$} \\
\hline $\operatorname{miR}-214$ & Ovarian Cancer & $\begin{array}{l}\text { Transcriptional control } \\
\text { (hedgehog signaling) }\end{array}$ & PTEN & Metastasis, chemoresistance & [129] \\
\hline miR-155 & Cervical Cancer & $\begin{array}{l}\text { miRNA sponge, transcriptional } \\
\text { control (c-MYB) }\end{array}$ & SOSC1 & Inflammation & [133] \\
\hline
\end{tabular}


Table 2. The impact of classified tumor-suppressive miRs on carcinogenic the signature through the specific target.

\begin{tabular}{|c|c|c|c|c|c|}
\hline $\begin{array}{ll}\text { miRNA } \\
\end{array}$ & Disease & Manipulating Mechanism & Candidate & Physiological Influence & Reference \\
\hline miR-1 & CRC & Epigenetic control; miRNA sponge & VEGF, NOTCH3 & Proliferation, migration, motility and metabolism & [25-27] \\
\hline miR-133 & CRC & Epigenetic control; miRNA sponge & FSCN1, SENP1 & Growth or motility of CRC cells & [28] \\
\hline miR-206 & CRC, LC & Epigenetic control; miRNA sponge & FMNL2, NOTCH33, BCL2, STA3, HIF-1, Coronin $1 \mathrm{C}$ & Migration, proliferation, and immortality, metastasis & {$[29,65,76]$} \\
\hline miR15/16 & CRC & Transcriptional control (SIRT1) & cyclin B1, TFAP-4, Bcl-2,K-Ras, MYB & Epithelial mesenchymal transition (EMT), apoptosis & {$[35-38]$} \\
\hline let-7 family & CRC; Cervical cancer & miRNA sponge & $\begin{array}{l}\text { PHD, ring finger domains 2, RTKN, IGF-1, MYC, } \\
\text { MMP11, PBX3, DCLK1, STAT3 }\end{array}$ & Cell cycle arrest, metastasis & {$[43-47,145,146]$} \\
\hline miR-125 & CRC Cervical Cancer & miRNA sponge & $\begin{array}{l}\text { Bcl-2, Mcl-1, SMURF1, VEGFA, CREB5, STAT3, } \\
\text { MMP-9, MMP-2, N-cadherin, }\end{array}$ & $\begin{array}{l}\text { Apoptosis, angiogenic or metastatic activity, } \\
\text { inflammaation }\end{array}$ & {$[50-52,146]$} \\
\hline let-7 family & LC & miRNA sponge & Ras & Proliferation & [57] \\
\hline miR-126 & LC & miRNA sponge & PTEN, CX3CR1 & Proliferation, metastasis & {$[58,73]$} \\
\hline miR-34 & LC; Cervical Cancer & Transcriptional control (p53) & Cyclin E2, HMGB1 & Cell cycle arrest & {$[59,141]$} \\
\hline miR-128 & LC & miRNA sponge & VEGFA, VEGFR2, VEGFR3 & Angiogenesis & [64] \\
\hline miR-135a & LC & miRNA sponge & IGF-1 & Angiogenesis & [66] \\
\hline 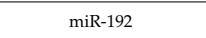 & LC & Transcriptional control (p53) & TRIM44 & Metastasis & [74] \\
\hline miR-7 & LC; Ovarian cancer & miRNA sponge & Nova2, EGFR & Angiogenesis, EMT & {$[75,137]$} \\
\hline miR-335 & LC & miRNA sponge & ROCK1 & EMT & [77] \\
\hline miR-98 & LC & miRNA sponge & TGF $\beta$ R1 & Proliferation, migration, and invasion & [78] \\
\hline miR-199 & $\mathrm{BC}$ & Transcriptional control (hedgehog signaling) & Ezh2, $\beta$-catenin, Ki-67 & Proliferation, migration, and invasion & [93-95] \\
\hline miR-214 & $\mathrm{BC}$ & Transcriptional control (hedgehog signaling) & Ezh2, $\beta$-catenin, Ki-67 & Proliferation, migration, and invasion & [93-95] \\
\hline miR-29 & нСС & Transcriptional control (NF- $\kappa B$, TGF- $\beta$ ) & CDC42, PIK3R1, BCl-2, Mcl-1 & Cell cycle, apoptosis & [112] \\
\hline miR-125b & HCC & Epigenetic, transcriptional control; miRNA sponge & Mcl-1 & Apoptosis & {$[115]$} \\
\hline miR-122 & НСС & Transcriptional control (C/EBP, HNF) & Cyclin G1, PKM2, and Wnt family member 1 & Cell cycle, apoptosis & [108] \\
\hline miR-150 & Ovarian cancer & miRNA sponge & ZEB1 & Invasion, metastasis & {$[134,135]$} \\
\hline miR-22, miR-183, miR-31 & Ovarian cancer & Transcriptional control (Snail) & TIAM1 & Invasion, migration & {$[136]$} \\
\hline miR-429 & Cervical Cancer & miRNA sponge & IL-6,IFN- $\beta$ & Chronic inflammation & [139] \\
\hline miR-142 & Cervical Cancer & miRNA sponge & HMGB1 & $\begin{array}{l}\text { Chronic inflammation, progressive tumorigenesis, } \\
\text { active metastasis }\end{array}$ & [141-143] \\
\hline miR-24 & Cervical Cancer & Uncertain & chitinase-3-like protein 1 & Proliferation, metastasis, inflammation & [144] \\
\hline miR-451 & Cervical Cancer & Uncertain & IL-6 receptor & Inflammation, invasion, angiogenesis, proliferation & {$[144]$} \\
\hline
\end{tabular}


Author Contributions: This work was conceived by J.-C.L. and P.-L.W. The original draft preparation and writing: Y.-C.L.; T.-H.C.; Y.-M.H.; P.-L.W.; J.-C.L. Review and editing: J.-C.L. All authors have read and agreed to the published version of the manuscript.

Funding: This work was supported by a grant (MOST 109-2622-B-038-002-CC3) from the Ministry of Science and Technology, Taiwan.

Institutional Review Board Statement: Not applicable.

Informed Consent Statement: Not applicable.

Data Availability Statement: Not applicable.

Conflicts of Interest: The authors declare no conflict of interest.

\section{References}

1. Akgül, B.; Erdoğan, I. Intracytoplasmic Re-localization of miRISC Complexes. Front. Genet. 2018, 9, 403. [CrossRef]

2. O'Brien, J.; Hayder, H.; Zayed, Y.; Peng, C. Overview of MicroRNA Biogenesis, Mechanisms of Actions, and Circulation. Front. Endocrinol. 2018, 9, 402. [CrossRef]

3. Bartel, D.P. MicroRNAs: Target Recognition and Regulatory Functions. Cell 2009, 136, 215-233. [CrossRef]

4. Di Leva, G.; Garofalo, M.; Croce, C.M. MicroRNAs in Cancer. Annu. Rev. Pathol. Mech. Dis. 2014, 9, 287-314. [CrossRef]

5. Ventura, A.; Jacks, T. MicroRNAs and Cancer: Short RNAs Go a Long Way. Cell 2009, 136, 586-591. [CrossRef]

6. Menigatti, M.; Staiano, T.; Manser, C.N.; Bauerfeind, P.; Komljenovic, A.; Robinson, M.; Jiricny, J.; Buoli, F.; Marra, G. Epige-netic silencing of monoallelically methylated miRNA loci in precancerous colorectal lesions. Oncogenesis 2013, 2, e56. [CrossRef]

7. Cui, M.; Wang, H.; Yao, X.; Zhang, D.; Xie, Y.; Cui, R.; Zhang, X. Circulating MicroRNAs in Cancer: Potential and Challenge. Front. Genet. 2019, 10, 626. [CrossRef] [PubMed]

8. Wong, M.Y.M.; Walsh, W.R.; Yu, Y.; Yang, J.-L. microRNA-34 family and treatment of cancers with mutant or wild-type p53 (Review). Int. J. Oncol. 2011, 38, 1189-1195. [CrossRef] [PubMed]

9. Mu, W.; Hu, C.; Zhang, H.; Qu, Z.; Cen, J.; Qiu, Z.; Li, C.; Ren, H.; Li, Y.; He, X.; et al. miR-27b synergizes with anticancer drugs via p53 activation and CYP1B1 suppression. Cell Res. 2015, 25, 477-495. [CrossRef] [PubMed]

10. Ju, Q.; Zhao, L.; Gao, J.; Zhou, L.; Xu, Y.; Sun, Y.; Zhao, X. Mutant p53 increases exosome-mediated transfer of miR-21-3p and miR-769-3p to promote pulmonary metastasis. Chin. J. Cancer Res. 2019, 31, 533-546. [CrossRef]

11. Bednarczyk, M.; Fatyga, E.; Dzięgielewska-Gęsiak, S.; Waniczek, D.; Grabarek, B.; Zmarzły, N.J.; Anikowska, G.; Muc-Wierzgoń, M. The Expression Paterns of BECN1, LAMP2, and PINK1 Genes in Colorectal Cancer Are Potentially Regu-lated by Micrornas and CpG Islands: An in Silico Study. J. Clin. Med. 2020, 9, 4020. [CrossRef]

12. Saito, Y.; Liang, G.; Egger, G.; Friedman, J.M.; Chuang, J.C.; Coetzee, G.A.; Jones, P.A. Specific activation of microRNA-127 with downregulation of the proto-oncogene BCL6 by chromatin-modifying drugs in human cancer cells. Cancer Cell 2006, 9, 435-443. [CrossRef]

13. Liang, Y.-J.; Wang, Q.-Y.; Zhou, C.-X.; Yin, Q.-Q.; He, M.; Yu, X.-T.; Cao, D.-X.; Chen, G.-Q.; He, J.-R.; Zhao, Q. MiR-124 targets Slug to regulate epithelial-mesenchymal transition and metastasis of breast cancer. Carcinogenesis 2012, 34, 713-722. [CrossRef]

14. Tsai, K.-W.; Wu, C.-W.; Hu, L.-Y.; Li, S.-C.; Liao, Y.-L.; Lai, C.-H.; Kao, H.-W.; Fang, W.-L.; Huang, K.-H.; Chan, W.-C.; et al. Epigenetic regulation of miR-34b and miR-129 expression in gastric cancer. Int. J. Cancer 2011, 129, 2600-2610. [CrossRef]

15. Wegert, J.; Ishaque, N.; Vardapour, R.; Georg, C.; Gu, Z.; Bieg, M.; Ziegler, B.; Bausenwein, S.; Nourkami, N.; Ludwig, N.; et al. Mutations in the SIX1/2 pathway and the DROSHA/DGCR8 miRNA microprocessor complex underlie high-Risk blastemal typeWilms tumors. Cancer Cell 2015, 27, 298-311. [CrossRef]

16. Hata, A.; Kashima, R. Dysregulation of microRNA biogenesis machinery in cancer. Crit. Rev. Biochem. Mol. Biol. 2016, 51, 121-134. [CrossRef]

17. De Kock, L.; Rivera, B.; Revil, T.; Thorner, P.; Goudie, C.; Soglio, D.B.-D.; Choong, C.S.; Priest, J.R.; Van Diest, P.J.; Tanboon, J.; et al. Sequencing of DICER1 in sarcomas identifies biallelic somatic DICER1 mutations in an adult-onset embryonal rhabdomyosarcoma. Br. J. Cancer 2017, 116, 1621-1626. [CrossRef]

18. Murray, M.J.; Bailey, S.M.; Raby, K.L.; Saini, H.K.; De Kock, L.A.A.; Burke, G.; Foulkes, W.D.; Enright, A.J.; Coleman, N.; Tischkowitz, M. Serum levels of mature microRNAs in DICER1-mutated pleuropulmonary blastoma. Oncog. 2014,3, e87. [CrossRef]

19. Waldman, S.A.; Terzic, A. A study of microRNAs in silico and in vivo: Diagnostic and therapeutic applications in cancer. FEBS J. 2009, 276, 2157-2164. [CrossRef]

20. Lee, Y.S.; Dutta, A. MicroRNAs in Cancer. Annu. Rev. Pathol. Mech. Dis. 2009, 4, 199-227. [CrossRef]

21. Siegel, R.L.; Miller, K.D.; Goding Sauer, A.; Fedewa, S.A.; Butterly, L.F.; Anderson, J.C.; Cercek, A.; Smith, R.A.; Jemal, A. Colorectal cancer statistics. CA Cancer J. Clin. 2020, 70, 145-164. [CrossRef]

22. Dave, V.P.; Ngo, T.A.; Pernestig, A.-K.; Tilevik, D.; Kant, K.; Nguyen, T.; Wolff, A.; Bang, D.D. MicroRNA amplification and detection technologies: Opportunities and challenges for point of care diagnostics. Lab. Investig. 2018, 99, 452-469. [CrossRef] [PubMed] 
23. Cheng, L.; Geng, L.; Dai, B.; Zheng, T.; Fuv, J.; Qiao, L.; Cai, W.; Wang, Y.; Yang, J. Repression of let-7a cluster prevents ad-hesion of colorectal cancer cells by enforcing a mesenchymal phenotype in presence of liver inflammation. Cell Death. Dis. 2018, 9, 489. [CrossRef] [PubMed]

24. Chen, J.-F.; Mandel, E.M.; Thomson, J.M.; Wu, Q.E.; Callis, T.; Hammond, S.M.; Conlon, F.L.; Wang, D.-Z. The Role of MicroRNA-1 and MicroRNA-133 in Skeletal Muscle Proliferation and Differentiation. Nat. Genet. 2005, 38, 228-233. [CrossRef]

25. Chen, W.-S.; Leung, C.-M.; Pan, H.-W.; Hu, L.-Y.; Li, S.-C.; Ho, M.-R.; Tsai, K.-W. Silencing of miR-1-1 and miR-133a-2 cluster expression by DNA hypermethylation in colorectal cancer. Oncol. Rep. 2012, 28, 1069-1076. [CrossRef] [PubMed]

26. Lei, X.; Li, L.; Duan, X. Long non-coding RNA ABHD11-AS1 promotes colorectal cancer development through regulation of miR-133a/SOX4 axis. Biosci. Rep. 2018, 38, 20181386. [CrossRef] [PubMed]

27. Yu, X.; Wang, D.; Wang, X.; Sun, S.; Zhang, Y.; Wang, S.; Miao, R.; Xu, X.; Qu, X. CXCL12/CXCR4 promotes inflamma-tion-driven colorectal cancer progression through activation of RhoA signaling by sponging miR-133a-3p. J. Exp. Clin. Cancer Res. 2019, 38, 32. [CrossRef]

28. Li, Z.; Liu, J.; Chen, H.; Zhang, Y.; Shi, H.; Huang, L.; Tao, J.; Shen, R.; Wang, T. Ferritin Light Chain (FTL) competes with long noncoding RNA Linc00467 for miR-133b binding site to regulate chemoresistance and metastasis of colorectal cancer. Carcinogenesis 2019, 41, 467-477. [CrossRef]

29. Zhu, D.; Sun, Y.; Zhang, D.; Dong, M.; Jiang, G.; Zhang, X.; Zhou, J. miR-1 inhibits the progression of colon cancer by regulating the expression of vascular endothelial growth factor. Oncol. Rep. 2018, 40, 589-598. [CrossRef]

30. Furukawa, S.; Kawasaki, Y.; Miyamoto, M.; Hiyoshi, M.; Kitayama, J.; Akiyama, T. The miR-1-NOTCH3-Asef Pathway Is Important for Colorectal Tumor Cell Migration. PLoS ONE 2013, 8, e80609. [CrossRef]

31. Xu, W.; Zhang, Z.; Zou, K.; Cheng, Y.; Yang, M.; Chen, H.; Wang, H.; Zhao, J.; Chen, P.; He, L.; et al. MiR-1 suppresses tumor cell proliferation in colorectal cancer by inhibition of Smad3-mediated tumor glycolysis. Cell Death Dis. 2017, 8, e2761. [CrossRef] [PubMed]

32. Zhou, G.-Q.; Han, F.; Shi, Z.-L.; Yu, L.; Li, X.-F.; Yu, C.; Shen, C.-L.; Wan, D.-W.; Zhu, X.-G.; Li, R.; et al. miR-133a-3p Targets SUMO-Specific Protease 1 to Inhibit Cell Proliferation and Cell Cycle Progress in Colorectal Cancer. Oncol. Res. Featur. Preclin. Clin. Cancer Ther. 2018, 26, 795-800. [CrossRef]

33. Meng, X.; Fu, R. miR-206 regulates 5-FU resistance by targeting Bcl-2 in colon cancer cells. OncoTargets Ther. 2018, ume 11, 1757-1765. [CrossRef]

34. Sun, L.N.; Zhi, Z.; Chen, L.Y.; Zhou, Q.; Li, X.M.; Gan, W.J.; Chen, S.; Yang, M.; Liu, Y.; Shen, T.; et al. SIRT1 suppresses col-orectal cancer metastasis by transcriptional repression of miR-15b-5p. Cancer. Lett. 2017, 409, 104-115. [CrossRef]

35. Wang, L.; Zhang, X.; Sheng, L.; Qiu, C.; Luo, R. LINC00473 promotes the Taxol resistance via miR-15a in colorectal cancer. Biosci. Rep. 2018, 38, 20180790. [CrossRef]

36. Liu, Y.; Zhou, J.; Wang, S.; Song, Y.; Zhou, J.; Ren, F. Long non-coding RNA SNHG12 promotes proliferation and invasion of colorectal cancer cells by acting as a molecular sponge of microRNA-16. Exp. Ther. Med. 2019, 18, 1212-1220. [CrossRef]

37. Dai, L.; Wang, W.; Zhang, S.; Jiang, Q.; Wang, R.; Dai, L.; Cheng, L.; Yang, Y.; Wei, Y.Q.; Deng, H.X. Vector-based miR-15a/16-1 plasmid inhibits colon cancer growth in vivo. Cell Biol. Int. 2012, 36, 765-770. [CrossRef]

38. Gopalan, V.; Ebrahimi, F.; Islam, F.; Vider, J.; Qallandar, O.B.; Pillai, S.; Lu, C.-T.; Lam, A.K.-Y. Tumour suppressor properties of miR-15a and its regulatory effects on BCL2 and SOX2 proteins in colorectal carcinomas. Exp. Cell Res. 2018, 370, 245-253. [CrossRef] [PubMed]

39. Shi, L.; Jackstadt, R.; Siemens, H.; Li, H.; Kirchner, T.; Hermeking, H. p53-induced miR-15a/16-1 and AP4 form a dou-ble-negative feedback loop to regulate epithelial-mesenchymal transition and metastasis in colorectal cancer. Cancer Res. 2014, 74, 532-542. [CrossRef]

40. Fesler, A.; Liu, H.; Ju, J. Modified miR-15a has therapeutic potential for improving treatment of advanced stage colorectal cancer through inhibition of BCL2, BMI1, YAP1 and DCLK. Oncotarget 2017, 9, 2367-2383. [CrossRef]

41. You, C.; Liang, H.; Sun, W.; Li, J.; Liu, Y.; Fan, Q.; Zhang, H.; Yue, X.; Li, J.; Chen, X.; et al. Deregulation of the miR-16-KRAS axis promotes colorectal cancer. Sci. Rep. 2016, 6, 37459. [CrossRef]

42. Yang, I.-P.; Tsai, H.-L.; Huang, C.-W.; Lu, C.-Y.; Miao, Z.-F.; Chang, S.-F.; Juo, S.-H.H.; Wang, J.-Y. High blood sugar levels significantly impact the prognosis of colorectal cancer patients through down-regulation of microRNA-16 by targeting Myb and VEGFR. Oncotarget 2016, 7, 18837-18850. [CrossRef] [PubMed]

43. Zhang, Z.; Feng, L.; Liu, P.; Duan, W. ANRIL promotes chemoresistance via disturbing expression of ABCC1 by regulating the expression of Let-7a in colorectal cancer. Biosci. Rep. 2018, 38, 20180620. [CrossRef] [PubMed]

44. Chen, H.; Xu, Z. Hypermethylation-Associated Silencing of miR-125a and miR-125b: A Potential Marker in Colorectal Cancer. Dis. Markers 2015, 2015, 1-7. [CrossRef]

45. Chen, D.; Sun, Q.; Zhang, L.; Zhou, X.; Cheng, X.; Zhou, D.; Ye, F.; Lin, J.; Wang, W. The lncRNA HOXA11-AS functions as a competing endogenous RNA to regulate PADI2 expression by sponging miR-125a-5p in liver metastasis of colorectal cancer. Oncotarget 2017, 8, 70642-70652. [CrossRef] [PubMed]

46. Li, W.; Yuan, F.; Zhang, X.; Chen, W.; Tang, X.; Lu, L. Elevated MIR100HG promotes colorectal cancer metastasis and is as-sociated with poor prognosis. Oncol. Lett. 2019, 18, 6483-6490. 
47. Sureban, S.M.; May, R.; Ramalingam, S.; Subramaniam, D.; Natarajan, G.; Wyche, J.H.; Anant, S.; Houchen, C.W. S1942 Selective Blockade of DCAMKL-1 Results in Tumor Growth Arrest by a Let-7a MicroRNA Dependent Mechanism. Gastroenterology 2009, 136, A-298. [CrossRef]

48. Wang, F.; Zhang, P.; Ma, Y.; Yang, J.; Moyer, M.P.; Shi, C.; Peng, J.; Qin, H. NIRF is frequently upregulated in colorectal cancer and its oncogenicity can be suppressed by let-7a microRNA. Cancer Lett. 2012, 314, 223-231. [CrossRef]

49. Li, B.; Chen, P.; Chang, Y.; Qi, J.; Fu, H.; Guo, H. Let-7a inhibits tumor cell growth and metastasis by directly targeting RTKN in human colon cancer. Biochem. Biophys. Res. Commun. 2016, 478, 739-745. [CrossRef]

50. Han, H.B.; Gu, J.; Zuo, H.J.; Chen, Z.G.; Zhao, W.; Li, M.; Ji, D.B.; Lu, Y.Y.; Zhang, Z.Q. Let-7c functions as a metastasis sup-pressor by targeting MMP11 and PBX3 in colorectal cancer. J. Pathol. 2012, 226, 544-555. [CrossRef]

51. Kohlan, A.K.; Saidijam, M.; Amini, R.; Samadi, P.; Najafi, R. Induction of let-7e gene expression attenuates oncogenic phenotype in HCT-116 colorectal cancer cells through targeting of DCLK1 regulation. Life Sci. 2019, 228, 221-227. [CrossRef] [PubMed]

52. Li, Z.; Pan, W.; Shen, Y.; Chen, Z.; Zhang, L.; Zhang, Y.; Luo, Q.; Ying, X. IGF1/IGF1R and microRNA let-7e down-regulate each other and modulate proliferation and migration of colorectal cancer cells. Cell Cycle 2018, 17, 1212-1219. [CrossRef]

53. Zhu, P.; Liu, J.; Lu, M.; Wu, G.; Lin, X.; Cai, L.; Zhang, X. Influence and mechanism of miR-99a suppressing development of colorectal cancer (CRC) with diabetes mellitus (DM). OncoTargets Ther. 2019, ume 12, 10311-10321. [CrossRef]

54. Tong, Z.; Liu, N.; Lin, L.; Guo, X.; Yang, D.; Zhang, Q. miR-125a-5p inhibits cell proliferation and induces apoptosis in colon cancer via targeting BCL2, BCL2L12 and MCL. Biomed. Pharmacother. 2015, 75, 129-136. [CrossRef]

55. Yang, X.; Qiu, J.; Kang, H.; Wang, Y.; Qian, J. miR-125a-5p suppresses colorectal cancer progression by targeting VEGFA. Cancer Manag. Res. 2018, ume 10, 5839-5853. [CrossRef]

56. Li, D.; Xu, X.; Miao, J.; Cai, J. MicroRNA-125a inhibits tumorigenesis by targeting Smurf1 in colorectal carcinoma. FEBS Open Bio 2019, 9, 1305-1314. [CrossRef]

57. Barta, J.A.; Powell, C.A.; Wisnivesky, J.P. Global Epidemiology of Lung Cancer. Ann. Glob. Health 2019, 85. [CrossRef]

58. Hwang, H.-W.; Mendell, J.T. MicroRNAs in cell proliferation, cell death, and tumorigenesis. Br. J. Cancer 2006, 94, 776-780. [CrossRef]

59. Navarro, F.; Lieberman, J. miR-34 and p53: New Insights into a Complex Functional Relationship. PLoS ONE 2015, 10, e0132767. [CrossRef] [PubMed]

60. Banzhaf-Strathmann, J.; Edbauer, D. Good guy or bad guy: The opposing roles of microRNA 125b in cancer. Cell Commun. Signal. 2014, 12, 30. [CrossRef] [PubMed]

61. Bublik, D.R.; Bursa 'c, S.; Sheffer, M.; Oršoli 'c, I.; Shalit, T.; Tarcic, O.; Kotler, E.; Mouhadeb, O.; Hoffman, Y.; Fuchs, G.; et al. Regulatory module involving FGF13, miR-504, and p53 regulates ribosomal biogenesis and supports cancer cell survival. Proc. Natl. Acad. Sci. USA 2017, 114, E496-E505. [CrossRef]

62. Chaffer, C.L.; Weinberg, R.A. A Perspective on Cancer Cell Metastasis. Science 2011, 331, 1559-1564. [CrossRef] [PubMed]

63. Wu, S.-G.; Chang, T.-H.; Liu, Y.-N.; Shih, J.-Y. MicroRNA in Lung Cancer Metastasis. Cancers 2019, 11, 265. [CrossRef] [PubMed]

64. Claperon, A.; Mergey, M.; Ho-Bouldoires, T.H.N.; Vignjevic, D.; Wendum, D.; Chretien, Y.; Merabtene, F.; Frazao, A.; Paradis, V.; Housset, C.; et al. EGF/EGFR axis contributes to the progression of cholangiocarcinoma through the induction of an epi-thelialmesenchymal transition. J. Hepatol. 2014, 61, 325-332. [CrossRef] [PubMed]

65. Thiery, J.P.; Acloque, H.; Huang, R.Y.; Nieto, M.A. Epithelial-Mesenchymal Transitions in Development and Disease. Cell 2009, 139, 871-890. [CrossRef] [PubMed]

66. Ma, L.; Teruya-Feldstein, J.; Weinberg, R.A. Tumour invasion and metastasis initiated by microRNA-10b in breast cancer. Nat. Cell Biol. 2007, 449, 682-688. [CrossRef]

67. Li, Y.; Li, Y.; Liu, J.; Fan, Y.; Li, X.; Dong, M.; Liu, H.; Chen, J. Expression levels of microRNA-145 and microRNA-10b are associated with metastasis in non-small cell lung cancer. Cancer Biol. Ther. 2016, 17, 272-279. [CrossRef]

68. Lou, W.; Liu, J.; Gao, Y.; Zhong, G.; Chen, D.; Shen, J.; Bao, C.; Xu, L.; Pan, J.; Cheng, J.; et al. MicroRNAs in cancer metastasis and angiogenesis. Oncotarget 2017, 8, 115787-115802. [CrossRef]

69. Mao, G.; Liu, Y.; Fang, X.; Liu, Y.; Fang, L.; Lin, L.; Liu, X.; Wang, N. Tumor-derived microRNA-494 promotes angiogenesis in non-small cell lung cancer. Angiogenesis 2015, 18, 373-382. [CrossRef]

70. Hu, J.; Cheng, Y.; Li, Y.; Jin, Z.; Pan, Y.; Liu, G.; Fu, S.; Zhang, Y.; Feng, K.; Feng, Y. microRNA-128 plays a critical role in human non-small cell lung cancer tumourigenesis, angiogenesis and lymphangiogenesis by directly targeting vascular endothelial growth factor-C. Eur. J. Cancer 2014, 50, 2336-2350. [CrossRef]

71. Xue, D.; Yang, Y.; Liu, Y.; Wang, P.; Dai, Y.; Liu, Q.; Chen, L.; Shen, J.; Ju, H.; Li, Y.; et al. MicroRNA-206 attenuates the growth and

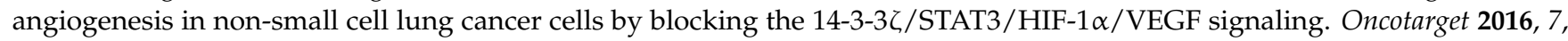
79805-79813. [CrossRef] [PubMed]

72. Zhou, Y.; Li, S.; Li, J.; Wang, D.; Li, Q. Effect of microRNA-135a on Cell Proliferation, Migration, Invasion, Apoptosis and Tumor Angiogenesis Through the IGF-1/PI3K/Akt Signaling Pathway in Non-Small Cell Lung Cancer. Cell Physiol. Biochem. 2017, 42, 1431-1446. [CrossRef] [PubMed]

73. Liu, R.; Zhang, Y.-S.; Zhang, S.; Cheng, Z.-M.; Yu, J.-L.; Zhou, S.; Song, J. MiR-126-3p suppresses the growth, migration and invasion of NSCLC via targeting CCR. Eur. Rev. Med. Pharmacol. Sci. 2019, 23, 679-689. [PubMed]

74. Xing, Y.; Meng, Q.; Chen, X.; Zhao, Y.; Liu, W.; Hu, J.; Xue, F.; Wang, X.; Cai, L. TRIM44 promotes proliferation and metastasis in non-small cell lung cancer via mTOR signaling pathway. Oncotarget 2016, 7, 30479-30491. [CrossRef] [PubMed] 
75. Xiao, H. MiR-7-5p suppresses tumor metastasis of non-small cell lung cancer by targeting NOVA. Cell. Mol. Biol. Lett. 2019, 24, 1-13. [CrossRef]

76. Liao, M.; Peng, L. MiR-206 may suppress non-small lung cancer metastasis by targeting CORO1C. Cell. Mol. Biol. Lett. 2020, 25, 1-13. [CrossRef]

77. Du, W.; Tang, H.; Lei, Z.; Zhu, J.; Zeng, Y.; Liu, Z.; Huang, J.-A. miR-335-5p inhibits TGF- $\beta 1$-induced epithelial-mesenchymal transition in non-small cell lung cancer via ROCK. Respir. Res. 2019, 20,1-11. [CrossRef] [PubMed]

78. Jiang, F.; Yu, Q.; Chu, Y.; Zhu, X.; Lu, W.; Liu, Q.; Wang, Q. MicroRNA-98-5p inhibits proliferation and metastasis in non-small cell lung cancer by targeting TGFBR. Int. J. Oncol. 2018, 54, 128-138. [CrossRef]

79. Chen, Q.; Chen, S.; Zhao, J.; Zhou, Y.; Xu, L. MicroRNA-126: A new and promising player in lung cancer (Review). Oncol. Lett. 2020, 21, 1. [CrossRef]

80. Chen, Z.; Wang, D.; Gu, C.; Liu, X.; Pei, W.; Li, J.; Cao, Y.; Jiao, Y.; Tong, J.; Nie, J. Down-regulation of let-7 microRNA increased K-ras expression in lung damage induced by radon. Environ. Toxicol. Pharmacol. 2015, 40, 541-548. [CrossRef]

81. Song, L.; Li, D.; Gu, Y.; Wen, Z.-M.; Jie, J.; Zhao, D.; Peng, L.-P. MicroRNA-126 Targeting PIK3R2 Inhibits NSCLC A549 Cell Proliferation, Migration, and Invasion by Regulation of PTEN/PI3K/AKT Pathway. Clin. Lung Cancer 2016, 17, e65-e75. [CrossRef] [PubMed]

82. Globocan, Estimated Cancer Incidence, Mortality et Prevalence Worldwide. Available online: http://globocan.iarc.fr/Default. aspx (accessed on 23 December 2020).

83. Kasiappan, R.; Rajarajan, D. Role of MicroRNA Regulation in Obesity-Associated Breast Cancer: Nutritional Perspectives. Adv. Nutr. 2017, 8, 868-888. [CrossRef] [PubMed]

84. Cantini, L.; Bertoli, G.; Cava, C.; Dubois, T.; Zinovyev, A.; Caselle, M.; Castiglioni, I.; Barillot, E.; Martignetti, L. Identification of microRNA clusters cooperatively acting on epithelial to mesenchymal transition in triple negative breast cancer. Nucleic Acids Res. 2019, 47, 2205-2215. [CrossRef] [PubMed]

85. Li, P.; Sheng, C.; Huang, L.; Zhang, H.; Huang, L.; Cheng, Z.; Zhu, Q. MiR-183/-96/-182 cluster is up-regulated in most breast cancers and increases cell proliferation and migration. Breast Cancer Res. 2014, 16, 473. [CrossRef]

86. Dambal, S.; Shah, M.; Mihelich, B.L.; Nonn, L. The microRNA-183 cluster: The family that plays together stays together. Nucleic Acids Res. 2015, 43, 7173-7188. [CrossRef]

87. Ma, Y.; Liang, A.-J.; Fan, Y.-P.; Huang, Y.-R.; Zhao, X.-M.; Sun, Y.; Chen, X.-F. Dysregulation and functional roles of miR-183-96-182 cluster in cancer cell proliferation, invasion and metastasis. Oncotarget 2016, 7, 42805-42825. [CrossRef]

88. Cao, D.; Di, M.; Liang, J.; Shi, S.; Tan, Q.; Wang, Z. MicroRNA-183 in Cancer Progression. J. Cancer 2020, 11, 1315-1324. [CrossRef]

89. Cheng, Y.; Xiang, G.; Meng, Y.; Dong, R. MiRNA-183-5p promotes cell proliferation and inhibits apoptosis in human breast cancer by targeting the PDCD. Reprod. Biol. 2016, 16, 225-233. [CrossRef] [PubMed]

90. Hong, Y.; Liang, H.; Rehman, U.-U.; Wang, Y.; Zhang, W.; Zhou, Y.; Chen, S.; Yu, M.; Cui, S.; Liu, M.; et al. miR-96 promotes cell proliferation, migration and invasion by targeting PTPN9 in breast cancer. Sci. Rep. 2016, 6, 37421. [CrossRef] [PubMed]

91. Guttilla, I.K.; White, B.A. Coordinate Regulation of FOXO1 by miR-27a, miR-96, and miR-182 in Breast Cancer Cells. J. Biol. Chem. 2009, 284, 23204-23216. [CrossRef]

92. Song, J.; Ouyang, Y.; Che, J.; Li, X.; Zhao, Y.; Yang, K.; Zhao, X.; Chen, Y.; Fan, C.; Yuan, W. Potential value of miR-221/222 as diagnostic, prognostic, and therapeutic biomarkers for diseases. Front. Immunol. 2017, 8, 1-9. [CrossRef]

93. Di Leva, G.; Gasparini, P.; Piovan, C.; Ngankeu, A.; Garofalo, M.; Taccioli, C.; Iorio, M.V.; Li, M.; Volinia, S.; Alder, H.; et al. MicroRNA Cluster 221-222 and Estrogen Receptor $\alpha$ Interactions in Breast Cancer. J. Natl. Cancer Inst. 2010, 102, 706-721. [CrossRef]

94. Li, B.; Lu, Y.; Wang, H.; Han, X.; Mao, J.; Li, J.; Yu, L.; Wang, B.; Fan, S.; Yu, X.; et al. MiR-221/222 enhance the tumorigenicity of human breast cancer stem cells via modulation of PTEN/Akt pathway. Biomed. Pharmacother. 2016, 79, 93-101. [CrossRef]

95. Alimirah, F.; Peng, X.; Gupta, A.; Yuan, L.; Welsh, J.E.; Cleary, M.; Mehta, R.G. Crosstalk between the vitamin D receptor (VDR) and miR-214 in regulating SuFu, a hedgehog pathway inhibitor in breast cancer cells. Exp. Cell Res. 2016, 349, 15-22. [CrossRef]

96. Derfoul, A.; Juan, A.H.; Difilippantonio, M.J.; Palanisamy, N.; Ried, T.; Sartorelli, V. Decreased microRNA-214 levels in breast cancer cells coincides with increased cell proliferation, invasion and accumulation of the Polycomb Ezh2 methyltransferase. Carcinogenesis 2011, 32, 1607-1614. [CrossRef]

97. Yi, S.-J.; Li, L.-L.; Tu, W.-B. MiR-214 negatively regulates proliferation and WNT/ $\beta$-catenin signaling in breast cancer. Eur. Rev. Med. Pharmacol. Sci. 2016, 20, 5148-5154.

98. Liu, B.; Tian, Y.; Like, Z.; Zhao, Z.; Jiang, X.; Zhai, C.; Han, X.; Zhang, L. Tumor-suppressing roles of miR-214 and miR-218 in breast cancer. Oncol. Rep. 2016, 35, 3178-3184. [CrossRef] [PubMed]

99. Wang, Y.; Liang, H.; Zhou, G.; Hu, X.; Liu, Z.; Jin, F.; Yu, M.; Sang, J.; Zhou, Y.; Fu, Z.; et al. HIC1 and miR-23 27 24 clusters form a double-negative feedback loop in breast cancer. Cell Death Differ. 2017, 24, 421-432. [CrossRef] [PubMed]

100. Hannafon, B.N.; Cai, A.; Calloway, C.L.; Xu, Y.-F.; Zhang, R.; Fung, K.-M.; Ding, W.-Q. miR-23b and miR-27b are oncogenic microRNAs in breast cancer: Evidence from a CRISPR/Cas9 deletion study. BMC Cancer 2019, 19, 1-12. [CrossRef] [PubMed]

101. Ell, B.; Qiu, Q.; Wei, Y.; Mercatali, L.; Ibrahim, T.; Amadori, D.; Kang, Y. The MicroRNA-23b/27b/24 Cluster Promotes Breast Cancer Lung Metastasis by Targeting Metastasis-suppressive Gene Prosaposin. J. Biol. Chem. 2014, 289, 21888-21895. [CrossRef] [PubMed] 
102. Li, M.; Han, Y.; Zhou, H.; Li, X.; Lin, C.; Zhang, E.; Chi, X.; Hu, J.; Xu, H. Transmembrane protein $170 \mathrm{~B}$ is a novel breast tu-morigenesis suppressor gene that inhibits the Wnt/ $\beta$-catenin pathway. Cell Death Dis. 2018, 9, 91. [CrossRef]

103. Pellegrino, L.; Stebbing, J.; Braga, V.M.; Frampton, A.E.; Jacob, J.; Buluwela, L.; Jiao, L.R.; Periyasamy, M.; Madsen, C.D.; Caley, M.P.; et al. miR-23b regulates cytoskeletal remodeling, motility and metastasis by directly targeting multiple transcripts. Nucleic Acids Res. 2013, 41, 5400-5412. [CrossRef]

104. Shiels, M.S.; O'Brien, T.R. Recent Decline in Hepatocellular Carcinoma Rates in the United States. Gastroenterology 2020, 158, 1503-1505. [CrossRef] [PubMed]

105. Chandan, K.; Sarwat, M. Role of microRNA and Long Non-Coding RNA in Hepatocellular Carcinoma. Curr. Pharm. Des. 2020, 26, 415-428. [CrossRef]

106. Ludwig, N.; Leidinger, P.; Becker, K.; Backes, C.; Fehlmann, T.; Pallasch, C.; Rheinheimer, S.; Meder, B.; Stähler, C.; Meese, E.; et al. Distribution of miRNA expression across human tissues. Nucleic Acids Res. 2016, 44, 3865-3877. [CrossRef] [PubMed]

107. Meng, F.; Henson, R.; Wehbe-Janek, H.; Ghoshal, K.; Jacob, S.T.; Patel, T. MicroRNA-21 regulates expression of the PTEN tumor suppressor gene in human hepatocellular cancer. Gastroenterology 2007, 133, 647-658. [CrossRef]

108. Liu, C.; Yu, J.; Yu, S.; Lavker, R.M.; Cai, L.; Liu, W.; Yang, K.; He, X.; Chen, S. MicroRNA-21 acts as an oncomir through multiple targets in human hepatocellular carcinoma. J. Hepatol. 2010, 53, 98-107. [CrossRef]

109. Zhou, J.; Yu, L.; Gao, X.; Hu, J.; Wang, J.; Dai, Z.; Wang, J.-F.; Zhang, Z.; Lu, S.; Huang, X.; et al. Plasma MicroRNA Panel to Diagnose Hepatitis B Virus-Related Hepatocellular Carcinoma. J. Clin. Oncol. 2011, 29, 4781-4788. [CrossRef]

110. Pineau, P.; Volinia, S.; McJunkin, K.; Marchio, A.; Battiston, C.; Terris, B.; Mazzaferro, V.; Lowe, S.W.; Croce, C.M.; Dejean, A miR-221 overexpression contributes to liver tumorigenesis. Proc. Natl. Acad. Sci. USA 2009, 107, 264-269. [CrossRef] [PubMed]

111. Fornari, F.; Gramantieri, L.; Ferracin, M.; Veronese, A.; Sabbioni, S.; Calin, G.A.; Grazi, G.L.; Giovannini, C.; Croce, C.M.; Bolondi, L.; et al. MiR-221 controls CDKN1C/p57 and CDKN1B/p27 expression in human hepatocellular carcinoma. Oncogene 2008, 27, 5651-5661. [CrossRef]

112. Jiang, J.; Gusev, Y.; Aderca, I.; Mettler, T.A.; Nagorney, D.M.; Brackett, D.J.; Roberts, L.R.; Schmittgen, T.D. Association of MicroRNA Expression in Hepatocellular Carcinomas with Hepatitis Infection, Cirrhosis, and Patient Survival. Clin. Cancer Res. 2008, 14, 419-427. [CrossRef]

113. Zhao, Y.-J.; Ju, Q.; Li, G.-C. Tumor markers for hepatocellular carcinoma. Mol. Clin. Oncol. 2013, 1, 593-598. [CrossRef]

114. Roderburg, C.; Urban, G.-W.; Bettermann, K.; Vucur, M.; Zimmermann, H.W.; Schmidt, S.; Janssen, J.; Koppe, C.; Knolle, P.; Castoldi, M.; et al. Micro-RNA profiling reveals a role for miR-29 in human and murine liver fibrosis. Hepatology 2010, 53, 209-218. [CrossRef]

115. Xiong, Y.; Fang, J.H.; Yun, J.P.; Yang, J.; Zhang, Y.; Jia, W.H.; Zhuang, S.M. Effects of microRNA-29 on apoptosis, tumor-igenicity, and prognosis of hepatocellular carcinoma. Hepatology 2010, 51, 836-845.

116. Xu, Y.; An, Y.; Wang, Y.; Zhang, C.; Zhang, H.; Huang, C.; Jiang, H.; Wang, X.; Li, X. miR-101 inhibits autophagy and enhances cisplatin-induced apoptosis in hepatocellular carcinoma cells. Oncol. Rep. 2013, 29, 2019-2024. [CrossRef] [PubMed]

117. Gong, J.; Zhang, J.-P.; Li, B.; Zeng, C.; You, K.; Chen, M.-X.; Yuan, Y.; Zhuang, S.-M. MicroRNA-125b promotes apoptosis by regulating the expression of Mcl-1, Bcl-w and IL-6R. Oncogene 2013, 32, 3071-3079. [CrossRef] [PubMed]

118. Girard, M.; Jacquemin, E.; Munnich, A.; Lyonnet, S.; Henrion-Caude, A. miR-122, a paradigm for the role of microRNAs in the liver. J. Hepatol. 2008, 48, 648-656. [CrossRef] [PubMed]

119. Xu, H.; He, J.-H.; Xiao, Z.-D.; Zhang, Q.-Q.; Chen, Y.-Q.; Zhou, H.; Qu, L.-H. Liver-enriched transcription factors regulate MicroRNA-122 that targets CUTL1 during liver development. Hepatology 2010, 52, 1431-1442. [CrossRef] [PubMed]

120. Szabo, G.; Bala, S. MicroRNAs in liver disease. Nat. Rev. Gastroenterol. Hepatol. 2013, 10, 542-552. [CrossRef] [PubMed]

121. NCI. Surveillance, Epidemiology, and End Results Program. Cancer Stat Facts: Ovarian Cancer. Available online: https: / / seer.cancer.gov / statfacts/html/ovary.html (accessed on 14 October 2019).

122. Bray, F.; Ferlay, J.; Soerjomataram, I.; Siegel, R.L.; Torre, L.A.; Jemal, A. Global cancer statistics 2018: GLOBOCAN estimates of incidence and mortality worldwide for 36 cancers in 185 countries. CA Cancer J. Clin. 2018, 68, 394-424. [CrossRef] [PubMed]

123. Ehdaivand, S.; WHO. Classification of Ovarian Neoplasms. Available online: https://www.pathologyoutlines.com/topic/ ovarytumorwhoclassif.html (accessed on 14 October 2019).

124. Berman, T.A.; Schiller, J.T. Human papillomavirus in cervical cancer and oropharyngeal cancer: One cause, two diseases. Cancer 2017, 123, 2219-2229. [CrossRef] [PubMed]

125. Pardini, B.; De Maria, D.; Francavilla, A.; Di Gaetano, C.; Ronco, G.; Naccarati, A. MicroRNAs as markers of progression in cervical cancer: A systematic review. BMC Cancer 2018, 18, 1-17. [CrossRef] [PubMed]

126. Flores, C.P.; García-Vázquez, R.; Rincón, D.G.; Ruiz-García, E.; De La Vega, H.A.; Marchat, L.A.; Vera, Y.M.S.; López-Camarillo, C. MicroRNAs driving invasion and metastasis in ovarian cancer: Opportunities for translational medicine (Review). Int. J. Oncol. 2017, 50, 1461-1476. [CrossRef] [PubMed]

127. Fang, Y.; Xu, C.; Fu, Y. MicroRNA-17-5p induces drug resistance and invasion of ovarian carcinoma cells by targeting PTEN signaling. J. Biol. Res. 2015, 22, 12. [CrossRef] [PubMed]

128. Yang, H.; Kong, W.; He, L.; Zhao, J.-J.; O’Donnell, J.D.; Wang, J.; Wenham, R.M.; Coppola, D.; Kruk, P.A.; Nicosia, S.V.; et al. MicroRNA Expression Profiling in Human Ovarian Cancer: miR-214 Induces Cell Survival and Cisplatin Resistance by Targeting PTEN. Cancer Res. 2008, 68, 425-433. [CrossRef] [PubMed] 
129. Shishodia, G.; Shukla, S.; Srivastava, Y.; Masaldan, S.; Mehta, S.; Bhambhani, S.; Sharma, S.; Mehrotra, R.; Das, B.C.; Bharti, A.C. Alterations in microRNAs miR-21 and let-7a correlate with aberrant STAT3 signaling and downstream effects during cervical carcinogenesis. Mol. Cancer 2015, 14, 1-13. [CrossRef]

130. Bumrungthai, S.; Ekalaksananan, T.; Evans, M.F.; Chopjitt, P.; Tangsiriwatthana, T.; Patarapadungkit, N.; Kleebkaow, P.; Luanratanakorn, S.; Kongyingyoes, B.; Worawichawong, S.; et al. Up-Regulation of miR-21 Is Associated with Cervicitis and Human Papillomavirus Infection in Cervical Tissues. PLoS ONE 2015, 10, e0127109. [CrossRef]

131. Xu, L.; Xu, Q.; Li, X.; Zhang, X. MicroRNA-21 regulates the proliferation and apoptosis of cervical cancer cells via tumor ne-crosis factor-alpha. Mol. Med. Rep. 2017, 16, 4659-4663. [CrossRef]

132. Zhang, Y.; Wang, Z.-C.; Zhang, Z.-S.; Chen, F. MicroRNA-155 regulates cervical cancer via inducing Th17/Treg imbalance. Eur. Rev. Med. Pharmacol. Sci. 2018, 22, 3719-3726.

133. Vang, S.; Wu, H.-T.; Fischer, A.; Miller, D.H.; MacLaughlan, S.; Douglass, E.; Steinhoff, M.; Collins, C.; Smith, P.J.S.; Brard, L.; et al. Identification of Ovarian Cancer Metastatic miRNAs. PLoS ONE 2013, 8, e58226. [CrossRef]

134. Jin, M.; Yang, Z.; Ye, W.; Xu, H.; Hua, X. MicroRNA-150 Predicts a Favorable Prognosis in Patients with Epithelial Ovarian Cancer and Inhibits Cell Invasion and Metastasis by Suppressing Transcriptional Repressor ZEB1. PLoS ONE 2014, 9, e103965. [CrossRef]

135. Lü, X.; Li, J.; Liang, S.; Jin, H.; Xu, C.; Ma, D. Tiam1, negatively regulated by miR-22, miR-183 and miR-31, is involved in migration, invasion and viability of ovarian cancer cells. Oncol. Rep. 2012, 27, 1835-1842. [CrossRef]

136. Loganathan, S.; Kandala, P.K.; Gupta, P.; Srivastava, S.K. Inhibition of EGFR-AKT Axis Results in the Suppression of Ovarian Tumors In Vitro and in Preclinical Mouse Model. PLoS ONE 2012, 7, e43577. [CrossRef] [PubMed]

137. Chen, Z.; Han, Y.; Song, C.; Wei, H.; Chen, Y.; Huang, K.; Li, S.; Ma, D.; Wang, S.; Wang, J. Systematic review and me-ta-analysis of the prognostic significance of microRNAs in cervical cancer. Oncotarget 2018, 9, 17141-17148. [CrossRef] [PubMed]

138. Fan, J.Y.; Fan, Y.J.; Wang, X.L.; Xie, H.; Gao, H.J.; Zhang, Y.; Liu, M.; Tang, H. miR-429 is involved in regulation of NF-kB activity by targeting IKKbeta and suppresses oncogenic activity in cervical cancer cells. FEBS Lett. 2017, 591, 118-128. [CrossRef] [PubMed]

139. Huang, F.; Lin, C.; Shi, Y.H.; Kuerban, G. MicroRNA-101 inhibits cell proliferation, invasion, and promotes apoptosis by reg-ulating cyclooxygenase-2 in Hela cervical carcinoma cells. Asian Pac. J. Cancer Prev. 2013, 14, 5915-5920. [CrossRef] [PubMed]

140. Chandrasekaran, K.S.; Sathyanarayanan, A.; Karunagaran, D. Downregulation of HMGB1 by miR-34a is sufficient to suppress proliferation, migration and invasion of human cervical and colorectal cancer cells. Tumor Biol. 2016, 37, 13155-13166. [CrossRef] [PubMed]

141. Chen, J.; Li, G. MiR-1284 enhances sensitivity of cervical cancer cells to cisplatin via downregulating HMGB1. Biomed. Pharmacother 2018, 107, 997-1003. [CrossRef]

142. Jiang, D.; Wang, H.; Li, Z.; Li, Z.; Chen, X.; Cai, H. MiR-142 inhibits the development of cervical cancer by targeting HMGB1. Oncotarget 2016, 8, 4001-4007. [CrossRef]

143. Sun, L.; Wang, D.; Li, H.; She, H. Significance of high YKL-40 expression regulated by miR-24 in cervical cancer progression and prognosis. Int. J. Clin. Exp. Pathol. 2016, 9, 5128-5137.

144. Liu, D.; Liu, C.; Wang, X.; Ingvarsson, S.; Chen, H. MicroRNA-451 suppresses tumor cell growth by down-regulating IL6R gene expression. Cancer Epidemiol. 2014, 38, 85-92. [CrossRef]

145. Fan, Z.; Cui, H.; Xu, X.; Lin, Z.; Zhang, X.; Kang, L.; Han, B.; Meng, J.; Yan, Z.; Yan, X.; et al. MiR-125a suppresses tumor growth, invasion and metastasis in cervical cancer by targeting STAT3. Oncotarget 2015, 6, 25266-25280. [CrossRef] [PubMed]

146. Chen, J.; Hu, C.; Pan, P. Extracellular Vesicle MicroRNA Transfer in Lung Diseases. Front. Physiol. 2017, 8, 1028. [CrossRef] [PubMed]

147. Behera, J.; Tyagi, N. Exosomes: Mediators of bone diseases, protection, and therapeutics potential. Oncoscience 2018, 5, 181-195. [CrossRef] [PubMed]

148. Mao, L.; Li, X.; Gong, S.; Yuan, H.; Jiang, Y.; Huang, W.; Sun, X.; Dang, X. Serum exosomes contain ECRG4 mRNA that suppresses tumor growth via inhibition of genes involved in inflammation, cell proliferation, and angiogenesis. Cancer Gene Ther. 2018, 25, 248-259. [CrossRef] [PubMed]

149. Wu, H.; Zhou, J.; Mei, S.; Wu, D.; Mu, Z.; Chen, B.; Xie, Y.; Ye, Y.; Liu, J. Circulating exosomal microRNA-96 promotes cell proliferation, migration and drug resistance by targeting LMO7. J. Cell. Mol. Med. 2016, 21, 1228-1236. [CrossRef]

150. Hsu, Y.-L.; Hung, J.-Y.; Chang, W.-A.; Lin, Y.-S.; Pan, Y.-C.; Tsai, P.-H.; Wu, C.-Y.; Kuo, P.-L. Hypoxic lung cancer-secreted exosomal miR-23a increased angiogenesis and vascular permeability by targeting prolyl hydroxylase and tight junction protein ZO-1. Oncogene 2017, 36, 4929-4942. [CrossRef]

151. Wei, F.; Ma, C.; Zhou, T.; Dong, X.; Luo, Q.; Geng, L.; Ding, L.; Zhang, Y.; Zhang, L.; Li, N.; et al. Exosomes derived from gemcitabine-resistant cells transfer malignant phenotypic traits via delivery of miRNA-222-3p. Mol. Cancer 2017, 16, 1-14. [CrossRef]

152. Jing, C.; Cao, H.; Qin, X.; Yu, S.; Wu, J.; Wang, Z.; Ma, R.; Feng, J. Exosome-mediated gefitinib resistance in lung cancer HCC827 cells via delivery of miR-21. Oncol. Lett. 2018, 15, 9811-9817. [CrossRef]

153. Aushev, V.N.; Zborovskaya, I.B.; Laktionov, K.K.; Girard, N.; Cros, M.-P.; Herceg, Z.; Krutovskikh, V. Comparisons of microRNA Patterns in Plasma before and after Tumor Removal Reveal New Biomarkers of Lung Squamous Cell Carcinoma. PLoS ONE 2013, 8, e78649. [CrossRef] 
154. Jin, X.; Chen, Y.; Chen, H.; Fei, S.; Chen, D.; Cai, X.; Liu, L.; Lin, B.; Su, H.; Zhao, L.; et al. Evaluation of Tumor-Derived Exosomal miRNA as Potential Diagnostic Biomarkers for Early-Stage Non-Small Cell Lung Cancer Using Next-Generation Sequencing. Clin. Cancer Res. 2017, 23, 5311-5319. [CrossRef] [PubMed]

155. Syn, N.L.; Wang, L.; Chow, E.K.-H.; Lim, C.T.; Goh, B.-C. Exosomes in Cancer Nanomedicine and Immunotherapy: Prospects and Challenges. Trends Biotechnol. 2017, 35, 665-676. [CrossRef] [PubMed]

156. Monfared, H.; Jahangard, Y.; Nikkhah, M.; Mirnajafi-Zadeh, S.J.; Mowla, S.J. Potential Therapeutic Effects of Exosomes Packed With a miR-21-Sponge Construct in a Rat Model of Glioblastoma. Front. Oncol. 2019, 9, 782. [CrossRef] [PubMed] 